FINANSIA: Jurnal Akuntansi dan Perbankan Syariah

P-ISSN: 2621-4636; E-ISSN: 2621-4644

Volume 02, Nomor 01, Januari-Juni 2019

Website: www.febi.metrouniv.ac.id; E-mail: jurnalfinansia@gmail.com

\title{
HAMBATAN IMPLEMENTASI \\ AKAD MUDHARABAH \\ PADA PT. BPR SYARIAH KOTABUMI \\ LAMPUNG UTARA
}

\author{
Istiqomah \\ Institut Agama Islam Negeri Metro \\ E-mail: istiqomah.iq49@gmail.com
}

Direvisi : Mei 2019

Diterbitkan: Juni 2019

\begin{abstract}
Mudarabat financing is an agreement between Shahibul Mall and Mudarib to carry out business activities. In Kotabumi Syariah BPR, mudharabah financing is classified as financing with a low number of customers. The purpose of this study is to determine the obstacles in the implementation of mudharabah contract in PT BPR Syariah Kotabumi. The research method used is a field research method that is descriptive qualitative in nature. Methods of data collection are interview methods and documentation. Analysis of the data used is a qualitative data analysis technique with inductive thinking. The low mudharabah financing of PT BPR Syariah Kotabumi is caused by several inhibiting factors which come from customers such as moral hazard risk, customer transparency, type of business financed by the bank, customer productivity in managing the business, small demand for financing from customers, and factors from internal bank, namely the absence of a supervisory board that fosters and directs customers in managing the business, the low interest of the bank in channeling mudharabah financing products, lack of competent marketing human resources. Efforts made by PT BPR Syariah Kotabumi to minimize obstacles in the implementation of mudharabah financing contracts, namely customer business feasibility analysis, providing financing to
\end{abstract}


customers with clear economic conditions, improving the quality of HR (Human Resources) internal BPR Syariah Kotabumi.

Keywords: Financing, Mudharabah, Implementation, Obstacles, and Risk.

\begin{abstract}
Abstrak
Pembiayaan mudarabat merupakan akad kerjasama antara shahibul mal dan mudarib untuk melaksanakan kegiatan usaha. Di BPR Syariah Kotabumi, pembiayaan mudharabah tergolong dalam pembiayaan dengan jumlah nasabah penyalurannya terhitung rendah. Adapun tujuan dari penelitian ini adalah untuk mengetahui hambatan dalam implementasi akad mudharabah di PT BPR Syariah Kotabumi. Metode penelitian yang digunakan adalah metode penelitian lapangan (field research) yang bersifat deskriptif kualitatif. Metode pengumpulan data yaitu metode wawancara dan dokumentasi. Analisis data yang digunakan adalah teknik analisis data kualitatif dengan cara berfikir induktif. Rendahnya pembiayaan mudharabah PT BPR Syariah Kotabumi disebabkan karena beberapa faktor penghambat yaitu berasal dari nasabah seperti risiko moral hazard, transparansi nasabah, jenis usaha yang dibiayai oleh pihak bank, produktifitas nasabah dalam mengelola usaha, permintaan pembiayaan bagi hasil masih kecil dari nasabah, dan faktor dari internal bank yaitu belum adanya dewan pengawas yang membina dan mengarahkan nasabah dalam mengelola usaha, rendahnya minat pihak bank dalam menyalurkan produk pembiayaan mudharabah, kurangnya SDM (Sumber Daya Manusia) pemasaran yang kompeten. Upaya yang dilakukan PT BPR Syariah Kotabumi untuk menimalisir hambatan dalam implementasi akad pembiayaan mudharabah yaitu analisis kelayakan usaha nasabah, memberikan pembiayaan kepada nasabah dengan keadaan ekonomi yang sudah jelas, meningkatkan kualitas SDM (Sumber Daya Manusia) internal BPR Syariah Kotabumi.
\end{abstract}

Kata Kunci: Pembiayaan, Mudharabah, Implementasi, Hambatan, dan Resiko. 


\section{A. Pendahuluan}

Dalam menjalankan tugas dan fungsinya, perbankan syariah juga tidak lepas dari pengertian dasar perbankan itu sendiri, yaitu sebagai badan usaha yang menghimpun dana masyarakat dalam bentuk simpanan dan menyalurkannya kepada masyarakat dalam bentuk kredit atau bentuk lainnya.

Pembiayaan Mudharabah adalah akad kerjasama usaha antara dua pihak dimana pihak pertama (shahibul mal) menyediakan dana seluruh (100\%) modal sedangkan pihak lainnya menjadi pengelola usaha (mudhrib). Keuntungan usaha secara mudharabah dibagi menurut kesepakatan yang dituangkan dalam kontrak. ${ }^{1}$

Sudah menjadi rahasia umum dikalangan masyarakat Islam khususnya para pemerhati ekonomi Islam dan orang-orang yang memiliki kepentingan dengan bank Islam, bahwa praktek Lembaga Keuangan Syariah (LKS) khususnya perbankan syariah lebih banyak menggunakan akad murabahah (hampir 70\%) dibandingkan dengan menggunakan akad mudharabah. ${ }^{2}$

Rendahnya penyaluran pembiayaan mudharabah pada Lembaga Keuangan Syariah dapat ditunjukkan dengan beberapa hasil penelitian di beberapa Lembaga Keuangan Syariah. Dalam penelitian yang ditulis oleh Muhammad Akhyar Adnan bahwa pada tahun 2013 untuk komposisi pembiayaan BPRS seluruh Indonesia dalam penyaluran pembiayaan mudharabah hanya memiliki nilai pangsa sebanyak 3,05\% dari total seluruh pembiayaan yang ada. Sedangkan untuk nilai pangsa penyaluran pembiayaan murabahah sebesar 79,10\%. . Dalam penelitian lain yang ditulis oleh Muhammad Chairul Anwar pada BPRS Sahara Tulung Agung menunjukkan bahwa penyaluran pembiayaan mudharabah masih sangat kurang

${ }^{1}$ Muhammad Syafi'i Antonio, Bank Syariah: Dari Teori ke Praktik (Jakarta: Gema Insani, 2001), h. 95.

${ }^{2}$ A. Chairul Hadi, Problematika Pembiayaan Mudharabah Di Perbankan Syariah Indonesia dalam MASLAHAH, Vol. 2, No. 1, Maret 2012, h.4.

${ }_{3}$ Muhammad Akhyar Adnan, Analisis Faktor-Faktor Yang Mempengaruhi Rendahnya Pembiayaan Mudharabah Menurut Perspektif Manajemen Bank Syariah Dengan Pendekatan Kritis (Studi Kasus Pada Tiga BPR Syariah di Yogyakarta), Skipsi, tahun 2013 
baik dengan presentase sebesar 8,47 \%. ${ }^{4}$ Dari beberapa penelitian diatas dapat diketahui bahwa dalam pengimplementasian akad mudharabah di lembaga keuangan syariah masih tertinggal jauh dibandingkan dengan pertumbuhan produk pembiayaan lainnya seperti pembiayaan murabahah maupun ijarah.

Bank syariah tidak dapat menyalurkan begitu saja sejumlah dana kepada mudharib atas dasar kepercayaan, karena selalu ada resiko bahwa pembiayaan yang telah diberikan kepada mudharib tidak dipergunakan sebagaimana mestinya untuk memaksimalkan keuntungan kedua belah pihak. Begitu dana dikelola oleh mudharib, maka akses informasi bank terhadap usaha mudharib menjadi terbatas. Dengan demikian, terjadi assymmetric information dimana mudharib mengetahui informasi-informasi yang tidak diketahui oleh bank. ${ }^{5}$ Assymmetric information yang dilakukan agen dalam kontrak keuangan biasanya berbentuk moral hazard dan adverse selection. Adverse selection terjadi pada kontrak utang ketika peminjam memiliki kualitas yang tidak baik atas kredit diluar batas ketentuan tingkat keuntungan tertentu, dan moral hazard terjadi ketika melakukan penyimpangan atau menimbulkan risiko yang lebih besar dalam kontrak. ${ }^{6}$

Pertumbuhan penyaluran pembiayaan mudharabah di BPR Syariah Kotabumi masih berada di tingkat bawah dibandingkan dengan produk pembiayaan lainnya. Hal tersebut dikarenakan pembiayaan dengan akad mudharabah ini memiliki tingkat risiko yang lebih besar dibandingkan dengan pembiayaan lain, seperti pembiayaan murabahah serta pembiayaan ijarah multijasa yang risiko lebih kecil. Hal tersebut disebabkan karena modal usaha untuk pembiayaan mudharabah sepenuhnya berasal dari pihak bank. Dari faktor itulah sebabnya pembiayaan mudharabah ini masih jarang disalurkan sebagai produk pembiayaan. Bahkan beberapa tahun yang lalu, pembiayaan ini sempat terhenti sementara. Hal tersebut

${ }^{4}$ Muhammad Chairul Anwar, Analisis Faktor-Faktor Penyebab Rendahnya Minat Penggunaan Pembiayaan Mudharabahdi BPRS Sahara Tulung Agung, Skripsi, Tahun 2015.

${ }^{5}$ Adiwarman A. Karim, Bank Islam., h. 214.

${ }^{6}$ Muhammad, Manajemen Bank., h. 367. 
terjadi karena beberapa faktor yang menunjukkan bahwa pihak bank tidak bisa memberikan pembiayaan tersebut kepada nasabah yang mengajukan pembiayaan. $^{7}$

Rendahnya skema mudharabah terjadi karena banyak hal yang menunjukkan bahwa pembiayaan mudharabah ini beresiko tinggi. ${ }^{8}$ Tingginya resiko inilah yang menjadikan komposisi penyaluran dana kepada masyarakat yang lebih banyak dalam bentuk pembiayaan perdagangan dibandingkan dengan bentuk penyertaan modal (mudharabah), padahal yang mempunyai dampak langsung kepada pertumbuhan ekonomi berupa tumbuhnya peluang usaha baru, kesempatan kerja baru, dan peningkatan pendapatan penduduk adalah pembiayaan dalam bentuk kerjasama yaitu mudharabah. ${ }^{9}$

Berdasarkan uraian tersebut diatas, topik ini menjadi sangat menarik untuk dibahas sehingga diperlukan penelitian yang lebih mendalam mengenai masalah tersebut. Dengan demikian,peneliti ingin membahasnya lebih lanjut dalam bentuk skripsi dengan judul: "HAMBATAN IMPLEMENTASI AKAD MUDHARABAH PADA PT BPR SYARIAH KOTABUMI DI KOTABUMI LAMPUNG UTARA".

\section{B. Implementasi Akad Mudharabah Pada PT BPR Syariah Kotabumi}

Pembiayaan mudharabah di BPR Syariah Kotabumi direalisasikan kepada nasabah pembiayaan dalam bentuk modal usaha yang bertujuan untuk mengembangkan usaha atau bisnisnya. Jumlah nasabah pembiayaan mudharabah tidak lebih dari $10 \%$ jumlah keseluruhan nasabah pembiayaan.

Pihak bank sangat selektif dan berhati-hati dalam memilih calon nasabah pembiayaan mudharabah. Adapun syarat untuk

${ }^{7}$ Wawancara, Bapak Taufik Hidayat, Remedial, PT BPR Syariah Kotabumi, Tanggal 25 April 2018

${ }^{8}$ Muhammad Akhyar Adnan dan Didi Purwoko, analisis faktor-faktor yang mempengaruhi rendahnya pembiayaan mudharabah menurut perspektif manajemen bank syariah dengan pendekatan kritis dalam JURNAL AKUTANSI DAN INVESTASI Vol. 14 No. 1, Januari 2013, h. 15

9 A. Chairul Hadi, Problematika Pembiayaan., h. 3. 
permohonan pembiayaan mudharabah yang ditetapkan oleh BPR Syariah Kotabumi antara lain: ${ }^{10}$

1. Mengisi aplikasi permohonan dengan lengkap dan jelas

2. Fotocopy KTP Pemohon (suami+istri) bagi calon nasabah yang telah menikah

3. Fotocopy rekening listrik ( 3 bulan terakhir)

4. Fotocopy rekening telepoon

5. Fotocopy rekening bank

6. Fotocopy surat nikah (bagi yang sudah menikah)

7. Surat persetujuan suami dan istri (bagi yang sudah menikah)

8. Surat keterangan usaha (dari Kepala Desa/Lurah)

9. Denah lokasi tempat usaha dan tempat tinggal. ${ }^{11}$

Syarat tersebut diatas harus dilengkapi oleh calon nasabah dengan tujuan agar pihak bank dapat menilai kelayakan dari calon nasabah sebelum dilakukannya tahapan prosedur pembiayaan. Tahapan prosedur pembiayaan mudharabah pada BPR Syariah Kotabumi antara lain sebagai berikut:

1. Pengajuan berkas oleh nasabah kepada bagian Funding Officer (FO)

2. Survey usaha dan jaminan nasabah

3. Rapat komite

4. Analisa kelengkapan berkas nasabah oleh Account Officer (AO)

5. Pengecekan oleh legal officer yang meliputi pengecekan jaminan, asuransi nasabah, dan identitas nasabah.

6. Pemeriksaan oleh Manager Marketing kemudian dilanjutkan dengan pemeriksaan keseluruhan

7. Persetujuan direksi

8. Akad pembiayaan

9. Pencairan pembiayaan.

10 Wawancara kepada bapak Tommy Adriansyah selaku Manager Marketing PT BPR Syariah Kotabumi, pada tanggal 21 Juni 2018 2018

${ }_{11}$ Dokumentasi profil BPR Syariah Kotabumi, dikutip tanggal 21 Juni 
Modal yang diberikan kepada nasabah tidak boleh melebihi nilai taksasi agunan yang telah dilakukan oleh pihak intern bank. Presentase nisbah bagi hasil mudharabah pada BPR Syariah Kotabumi yaitu 70\% : 30\%, 60\% : 40\%, 50\% : 50\%. Misalnya untuk porsi bagi hasil 70\% : 30\%, maka 70\% dari keuntungan usaha akan menjadi milik bank, sedangkan 30\% dari hasil usaha menjadi milik nasabah. Namun dalam realisasi pemberian pembiayaan mudharabah, nisbah bagi hasil yang ditetapkan pada awal akad yaitu dalam bentuk persentase.

Prinsip bagi hasil yang dilakukan antara pihak bank dan nasabah yaitu ditetapkan berdasarkan metode revenue sharing. Revenue sharing yaitu metode pembagian hasil usaha berdasarkan pendapat usaha bukan keuntungan bersih usaha. ${ }^{12}$

Pengembalian modal dari shahibul mal dilakukan secara angsuran tiap bulannya. Berikut adalah contoh perhitungan angsuran oleh pihak nasabah kepada BPRS:

Plafond Pembiayaan

Jangka waktu pembiayaan

Nisbah bagi hasil

Angsuran per bulan:

Bulan ke-1

Angsuran pokok

$$
=\operatorname{Rp} 100.000 .000: 36 \text { bulan }
$$$$
=\operatorname{Rp} 2.777 .800
$$

Margin (Bank)

$$
=\operatorname{Rp} 5.000 .000 \times 70 \%
$$$$
=\operatorname{Rp} 3.500 .000
$$

Angsuran ke-1

$$
\begin{aligned}
& =\text { Pokok }+ \text { Margin } \\
& =\operatorname{Rp} 2.777 .800+\operatorname{Rp} 3.500 .000 \\
& =\operatorname{Rp} 6.277 .800,-
\end{aligned}
$$

Jadi, angsuran oleh nasabah kepada bank syariah pada bulan ke-1 adalah Rp 6.277.800,-. 
Bulan ke-2

Angsuran pokok $\quad=\operatorname{Rp} 100.000 .000: 36$ bulan

$=\operatorname{Rp} 2.777 .800$

Margin (Bank) $\quad=\operatorname{Rp} 4.200 .000 \times 70 \%$

$=\operatorname{Rp} 2.940 .000$

Angsuran ke-2

$$
\begin{aligned}
& =\text { Pokok+Margin } \\
& =\operatorname{Rp} 2.777 .800+\operatorname{Rp} 2.940 .000 \\
& =\operatorname{Rp} 5.717 .800
\end{aligned}
$$

Jadi, angsuran oleh nasabah kepada bank syariah pada bulan ke-2 adalah Rp 5.717.800

Bulan ke-3

$$
\begin{array}{ll}
\text { Angsuran pokok } & =\operatorname{Rp} 100.000 .000: 36 \text { bulan } \\
& =\operatorname{Rp} 2.777 .800 \\
\text { Margin (Bank) } & =\operatorname{Rp} 7.000 .000 \times 70 \% \\
& =\operatorname{Rp} 4.900 .000 \\
\text { Angsuran ke-3 } & =\operatorname{Pok} \text { ok+Margin } \\
& =\operatorname{Rp} 2.777 .800+\operatorname{Rp} 4.900 .000 \\
& =\operatorname{Rp} 6.777 .800
\end{array}
$$

Jadi, angsuran oleh nasabah kepada bank syariah pada bulan ke-3 adalah Rp 6.777 .800

Dari contoh perhitungan diatas dapat diketahui bahwa jumlah angsuran oleh nasabah kepada pihak bank dapat berbedabeda tiap bulannya disesuaikan dengan jumlah keuntungan yang didapatkan dari usaha yang dijalankan oleh nasabah. Semakin besar keuntungan yang didapatkan nasabah maka semakin tinggi juga margin keuntungan yang didapatkan pihak bank.

Pembayaran angsuran dilakukan berdasarkan jangka waktu yang telah ditetapkan pada awal akad. Namun nasabah dapat melunasi kewajiban angsuran atas pengembalian modal dan keuntungan sebelum jatuh tempo akhir pembiayaan. Namun jika sampai akhir jangka waktu pemberian pembiayaan tidak diperoleh pengembalian modal beserta keuntungannya, maka pihak bank 
akan mengambil tindakan dengan cara menjual agunan yang telah dijaminkan kepada pihak bank. ${ }^{13}$

\section{Faktor Yang Mempengaruhi Akad Mudharabah di PT BPR Syariah Kotabumi}

Beberapa faktor yang mempengaruhi akad pembiayaan mudharabah di PT BPR Syariah Kotabumi terdiri dari beberapa hal, yaitu:

\section{Minat nasabah}

Nasabah BPR Syariah Kotabumi masih sedikit yang menggunakan pembiayaan mudharabah sebagai sarana pemenuhan kebutuhan nasabah. Sampai saat ini pembiayaan di BPRS ini masih didominasi oleh pembiayaan ijarah multijasa dan murabahah yang dianggap lebih mudah dan efektif untuk diajukan.

\section{Porsi bagi hasil}

Bagi nasabah porsi bagi hasil yang didapatkan oleh pihak nasabah dianggap kurang adil. Hal itu disebabkan porsi bagi hasil ynag didapatkan bank lebih besar dibandingkan nasabah, padahal nasabah sebagai pengelola lebih mengorbankan banyak tenaga, fikiran dan waktu. ${ }^{14}$ Sedangkan menurut pihak bank, porsi bagi hasil telah disesuaikan dengan kemungkian kerugian yang akan dialami dari pembiayaan yang diberikan.

\section{Pembayaran angsuran}

Pembayaran angsuran merupakan aspek penting dalam perolehan keuntungan pihak bank. Apabila terjadi penunggakan pembayaran, maka dapat menghambat perolehan keuntungan serta memperlambat sirkulasi perputaran modal oleh bank. Penunggakan pembayaran juga dapat mempersulit bank dalam pemberian fee atas bagi hasil kepada nasabah penghimpun dana.

\footnotetext{
13 Wawancara kepada bapak Tommy Adriansyah selaku Manager Marketing PT BPR Syariah Kotabumi, pada tanggal 21 Juni 2018 2018.

${ }_{14}$ Wawancara kepada nasabah (Bapak Aris) pada tanggal 20 Agustus
} 
Ijarah multijasa masih menjadi produk unggulan dalam hal pembiayaan. Pengajuannya terhitung mudah dan cepat terhitung 1-30 hari pengajuan pembiayaan. Berbeda dengan pembiayaan mudharabah yang memakan waktu yang lama yaitu 1-60 hari dari proses persetujuannya, karena tergolong beresiko sehingga perlu dilakukannya analisis pembiayaan menyeluruh. Lamanya waktu persetujuan pencairan pembiayaan mudharabah menyebabkan rendahnya minat nasabah untuk mengajukan pembiayaan ini. ${ }^{15}$

\section{Upaya Minimalisasi Hambatan Implementasi Akad Mudharabah di PT BPR Syariah Kotabumi}

Pembiayaan mudharabah di PT BPR Syariah mengalami beberapa hambatan dalam implementasinya sebagai salah satu produk pembiayaan untuk nasabah, yaitu:

\section{Hambatan dari nasabah}

\section{a. Nasabah belum memiliki usaha yang pasti}

Pihak bank masih cenderung enggan memberikan pembiayaan mudharabah kepada nasabah, hal tersebut dikarenakan nasabah belum memiliki usaha yang pasti. Hal tersebut dikarenakan rata-rata usaha nasabah belum memberikan kepastian usaha dan resiko yang akan dihadapinya. Pihak bank selaku pemilik dana akan sangat memperhitungkan kedua faktor tersebut dikarenakan apabila terjadi kerugian usaha maka akan ditanggung oleh pihak bank.

\section{b. Sedikitnya minat nasabah pada pembiayaan bagi hasil}

Hal ini dapat diidentifikasikan dari jumlah nasabah yang mengajukan pembiayaan mudharabah di bank. Umumnya nasabah di BPR Syariah Kotabumi lebih memilih menggunakan pembiayaan dengan akad ijarah multijasa ataupun murabahah. Nasabah mengganggap bahwa untuk pengajuan pembiayaan mudharabah lebih rumit

15 Wawancara kepada bapak Tommy Adriansyah selaku Manager Marketing PT BPR Syariah Kotabumi, pada tanggal 23 Agustus 2018 
dan membutuhkan waktu yang lama untuk pencairannya (1-60 hari).

\section{Hambatan dari Bank}

a. Tingkat kepercayaan bank terhadap nasabah tinggi resikonya

Hal ini berkaitan dengan prinsip kehati-hatian pihak bank dalam memilih dan memberikan pembiayaan kepada nasabah. Pembiayaan mudharabah ini mengandung ketidakpastian keuntungan. Pihak bank selaku pemilik modal akan mempertimbangkan resiko-resiko yang akan timbul pada usaha karena apabila terjadi kerugian maka pihak yang menanggung keugian adalah pihak bank. Alasannya ingin melindungi dana nasabah penghimpun dana (funding) dari risiko gagal bayar oleh nasabah pembiayaan.

\section{b. Promosi pembiayaan mudharabah oleh pihak bank}

Hal ini dapat terlihat dari jumlah nasabah pembiayaan mudharabah yang rendah. BPR Syariah Kotabumi belum memaksimalkan promosi dan pengenalan pembiayaan mudharabah kepada masyarakat umum dan nasabahnya. Pihak bank kurang mampu mengenalkan dan memasarkan pembiayaan mudharabah kepada nasabah, sehingga masih banyak nasabah yang belum mengenal pembiayaan dengan skema bagi hasil (mudharabah). ${ }^{16}$

Hambatan-hambatan diatas mengakibatkan rendahnya penyaluran pembiayaan mudharabah dibandingkan dengan akad pembiayaan lainnya seperti ijarah multijasa dan pembiayaan murabahah. ${ }^{17}$ Sehingga PT BPR Syariah melakukan beberapa upaya dalam menimalisir hambatan implementasi akad mudarabat, yaitu terdiri dari:

\footnotetext{
16 Wawancara kepada Bapak Tommy Adriansyah selaku Manager Marketing PT BPR Syariah Kotabumi, pada tanggal 21 Juni 2018

${ }_{17}$ Wawancara kepada Bapak Agus Prasetyo selaku Legal Officer PT BPR Syariah Kotabumi, pada tanggal 21 Juni 2018
} 


\section{Analisis kelayakan usaha nasabah}

Pada tahap seleksi pemberian pembiayaan mudharabah akan dilakukan analisis terhadap kelayakan usaha nasabah yang terdiri dari beberapa tahapan, yaitu:

a. Analisa aspek $5 \mathrm{C}$

1) Character

Menggambarkan watak dan kepribadian calon nasabah. Tujuannya untuk mengetahui bahwa calon nasabah mempunyai keinginan untuk memenuhi kewajiban membayar kembali pembiayaan yang telah diterima hingga mengembalikan kembali pembiayaan yang telah diterima hingga lunas. Cara yang dilakukan bank antara lain:

a. BI Checking

b. Informasi dari pihak lain

2) Capacity

Analisis ini ditujukan untuk mengetahui kemampuan keuangan calon nasabah dalam memenuhi kewajibannya sesuai jangka waktu pembiayaan. Bank perlu mengetahui dengan pasti kemampuan keuangan calon nasabah dalam memenuhi kewajibannya. Cara yang ditempuh untuk mengetahui kemampuan keuangan nasabah antara lain:

a. Melihat laporan keuangan

b. Memeriksa slip gaji dan rekening tabungan

c. Survey lokasi usaha nasabah

3) Capital

Capital atau modal yang perlu disertakan dalam objek pembiayaan perlu dilakukan analisis yang lebih mendalam. Hal tersebut dilakukan dengan cara melihat laporan keuangan calon nasabah

4) Collateral

Merupakan agunan yang diberikan oleh calon nasabah atas pembiayaan yang diajukan. Agunan merupakan sumber agunan yang kedua. Dalam hal apabila nasabah tidak dapat membayar angsurannya, maka bank syariah Kotabumi dapat 
melakukan penjualan terhadap agunan. Hasil penjualan agunan digunakan untuk melunasi pembiayaan.

5) Condition

Merupakan analisis terhadap kondisi perekonomian. Bank akan mempertimbangkan sektor usaha calon nasabah yang akan dikaitkan dengan kondisi ekonomi bank perlu melakukan analisis dampak kondisi ekonomi terhadap usaha calon nasabah dimasa yang akan datang untuk mengetahui pengaruh ekonomi terhadap usaha calon nasabah.

Dalam analisis kelayakan usaha yang menjadi prinsip penting dalam penilaian nasabah yaitu character, capacity dan collateral.

a. Membuat usulan pembiayaan dan tujuan pembiayaan

b. Mengetahui kewajiban besarnya pembiayaan dikaitkan dengan volume usaha calon nasabah.

c. Menghitung nisbah bagi hasil.

d. Data laporan keuangan.

e. Penilaian agunan.

\section{Meningkatkan Strategi Promosi Pembiayaan Mudharabah}

Rendahnya jumlah nasabah dalam penyaluran pembiayaan mudharabah dikarenakan salah satu faktornya yaitu masih banyak masyarakat dan nasabah belum mengetahui dan mengenal pembiayaan mudharabah. Sehingga pihak bank akan meningkatkan strategi promosi untuk pengenalan pembiayaan mudharabah kepada masyarakat melalui media cetak, online, radio dan televisi lokal serta sarana promosi lainnya.

Upaya-upaya tersebut dilakukan oleh BPR Syariah Kotabumi untuk menimalisir adanya hambatan dalam penyaluran pembiayaan mudarabat kepada nasabah pembiayaan. Sehingga diupayakan agar pembiayaan mudarabat dapat disalurkan kepada nasabah secara maksimal. 


\section{E. Kesimpulan}

Berdasarkan hasil penelitian tentang hambatan implementasi akad mudharabah pada PT BPR Syariah Kotabumi di Kotabumi Lampung Utara, dapat disimpulkan bahwa terdapat hambatan dalam penyaluran pembiayaan mudharabah pada PT BPR Syariah Kotabumi di Kotabumi Lampung Utara. Adapun yang menjadi hambatan dalam penerapan pembiayaan mudharabah pada PT BPR Syariah Kotabumi, yaitu:

\section{Hambatan dari nasabah}

a. Nasabah belum memiliki usaha yang pasti

b. Rendahnya minat nasabah terhadap pembiayaan bagi hasil

\section{Hambatan dari Bank}

a. Tingkat kepercayaan bank terhadap nasabah tinggi resikonya

b. Promosi pembiayaan mudharabah belum maksimal dilakukan oleh pihak bank

Upaya yang dilakukan untuk menimalisir hambatan dalam implementasi akad pembiayaan mudharabah di PT BPR Syariah Kotabumi yaitu:

1. Analisis kelayakan usaha nasabah

2. Meningkatkan Strategi Promosi Pembiayaan Mudharabah diarahkan kepada lembaga peradilan umum (khususnya sengketa hak milik) karena sudah sesuai dengan UU Republik Indonesia No. 7 Tahun 1989. Tahapan peradilan agama ini merupakan tahapan yang paling terakhir dilakukan, jika ternyata dalam tahapan perdamaian (sulh) maupun arbitrase baik secara kekeluargaan (ad hoc) maupun melalui arbitrase resminya telah gagal menghasilkan keputusan yang mengunt ungkan bagi pihak yang bersengketa. 


\section{DAFTAR PUSTAKA}

al-Munawwar, Said Agil Husin, Pelaksanaan Arbitrase di Dunia Islam Dalam Arbitrase Islam di Indonesia, Jakarta: BAMUI dan BMI, 1994

al-Suyuthi, Jamaluddin, Syarh al-Hafiz Sunan al-Nasa i, Beirut: alMaktabah al-Imrah, t.th., Juz VII

al-Zuhaily, Wahbah, al-Fiqh al-Islam wa Adillatuhu: al-Fiqh al-'Am, Kairo: Dar al-Fikr, 1985, Juz VII

Butarbutar, Elisabeth Nurhaini, Konsep Keadilan Dalam Sistem Peradilan Perdata, Mimbar Hukum, Vol.21, Nomor 2, Juni 2009

Djamil, Faturrahman, Penyelesaian Pembiayaan Bermasalah Di Bank Syariah, Jakarta, Sinar Grafika, Cet.ke-2, Juni 2014

Djauhari, Achmad, Peran Arbitrase Dalam Sistem Ekonomi Syariah, Makalah Seminar Nasional Reformulasi Sistem Ekonomi Syariah dan Legislasi Nasional BPHN Departemen Hukum dan HAM RI, Semarang 6-8 Juni 2006

Hamid, Asyur Abdul Jawad Abdul, al-Nid\}am Li al Bunuk al Islami, Al Ma'had al-'Alamy li al-Fikr al-Islami\}, Cairo, Mesir, 1996

Lewis, Bernard, Encyclopedia of Islam, Leiden: t.p., t.th., Vol.VIII Junaidi, Heri, Penyelesaian Sengketa Perjanjian Syari'ah Pada Lembaga

Keuangan Syari'ah, diakses dari http:/ / heriju-naidi.blogspot.

com/2011/02/penyelesaian-sengketa-perjanjian.html pada tanggal 22 Mei 2015 pukul 21.06 WIB

Katz, Avery W., Review: Contract Theory- Who Needs It?, The University of Chicago Law Review, Vol.81, No.4, (Fall 2014), diakses pada 24 Mei 2015 Pukul 15.11 WIB.

Lubis, Gala Perdana Putra Lubis, Analisis Putusan Mahkamah Konstitusi No. 93/ PUU-X/2012 Terhadap Penyelesaian Sengketa Perbankan Syariah di Indonesia, tp.th., tp.pnrbit. 
Mardani, Penyelesaian Sengketa Bisnis Syariah, Hukum Acara Perdata Peradilan Agama dan Mahkamah Syar'iyah, Jakarta, Sinar Grafika, 2009

Ma'luf, Luwis, Al-Munjid fi Al-Lughah wa al-A'lam, Beirut: Dar al- Mashriq, t.th.

Muhammad, Abu al-'Ainain Abdul Fattah, Al-Qadla wa al-Itsbat fi alFigh al-Islami, Mesir: Dar al-Fikr, 1976

Munawir, AW, Kamusal-Munawir, Yogyakarta,Pondok Pesantren al- Munawir, 1984

Sjahdeini, Sutan Remy, Perbankan Syariah Produk-produk dan Aspek- aspek Hukumnya, Jakarta, Kencana Prenadamedia Group, Cet. ke-1, Juni 2014

Subekti, R., Hukum Acara Perdata, Bandung, BPHN, Bina Cipta, Cet.Pertama, 1977.

Syafi'i Antonio, Muhammad, Bank Syariah: Dari Teori ke Praktik, Jakarta, Gema Insani Press, Cet.ke-1, 2001

Thaib, Hasballah dan Zamakhsyari Hasballah, Tafsir Tematik AlQur'an V, Medan, Pustaka Bangsa, 2008

Wahyudi, M. Isna, Harmonisai Hukum Dalam Penyelesaian Sengketa Ekonomi Syariah Melalui Peraturan Mahkamah Agung (PERMA), tnp. Thun, dan tnp.penerbit.

Yulianti, Rahmani Timorita, Asas-asas Perjanjian (Akad) Dalam Hukum Kontrak Syariah, Jurnal Ekonomi Islam La_Riba, Vol.II, No.1 Juli 2008

UU Republik Indonesia No. 3 Tahun 2006 Tentang Perubahan Atas Undang-undang No. 7 Tahun 1989 Tentang Peradilan Agama

UU Republik Indonesia No. 21 Tahun 2008 Tentang Perbankan Syariah 